\title{
Papillary atrophy of the tongue and nutritional status of hospitalized alcoholics
}

\author{
Glossite atrófica e estado nutricional de alcoolistas hospitalizados
}

\author{
Selma Freire de Carvalho da Cunha ${ }^{1}$ \\ Camila Bitu Moreno Braga ${ }^{3}$ \\ Daniel Ferreira da Cunha ${ }^{5}$
}

\author{
Daniel Angelo de Melo $^{2}$ \\ Helio Vannucchi ${ }^{4}$
}

\begin{abstract}
BACKGROUND: Atrophy of the papillae, mucosa, and dorsum of the tongue are considered classical signs of nutritional deficiencies.

OBJECTIVE: To assess the nutritional status of hospitalized alcoholics with or without papillary atrophy of the tongue.

METHODS: This study was performed with 21 hospitalized alcoholics divided into Atrophic Glossitis Group $(\mathrm{n}=13)$ and Normal Tongue Group $(n=8)$. Healthy, non-alcoholic volunteers composed the Control Group $(n=8)$. Anthropometry and bioelectric impedance were performed, and serum vitamins A, E, and B12 were determined.

RESULTS: There were no statistical differences in relation to age ( $46.7 \pm 8.7$ vs. $46.8 \pm 15.8$ years) or gender $(92.3 \%$ vs. $87.5 \%$ male), respectively. Control Group volunteers were also paired in relation to age (47.5 \pm 3.1 years) and male predominance (62.5\%). In relation to hospitalized alcoholics without atrophic lesions of the tongue and Control Group, patients with papillary atrophy showed lower BMI $\left(18.6 \pm 2,5\right.$ vs $\left.23.8 \pm 3.5 \mathrm{vs} 26.7 \pm 3,6 \mathrm{~kg} / \mathrm{m}^{2}\right)$ and body fat content $7.6 \pm 3.5 \mathrm{vs} 13.3 \pm 6.5$ vs $19.5 \pm 4,9 \mathrm{~kg}$ ). When compared with the Control Group, alcoholic patients with or without papillary atrophy of the tongue showed lower values of red blood cells $(10.8 \pm 2.2$ vs $11.8 \pm 2.2$ vs $14.5 \pm 1,6 \mathrm{~g} / \mathrm{dL})$ and albumin $(3.6 \pm 0.9$ vs $3.6 \pm 0.8$ vs $4.4 \pm 0.2 \mathrm{~g} / \mathrm{dL}$ ). The seric levels of vitamins $\mathrm{A}, \mathrm{E}$, and B12 were similar amongst the groups.

Conclusion: Hospitalized alcoholics with papillary atrophy of the tongue had lower BMI and fat body stores than controls, without associated hypovitaminosis.
\end{abstract}

Keywords: Alcoholism; Anthropometry; Glossitis; Tongue diseases; Vitamins

Resumo: FunDAmENTOS: A deficiência crônica de nutrientes pode levar à hipotrofia das papilas e da mucosa e do dorso da língua, considerada um sinal clássico de subnutrição protéico-energética.

OвJETIV: O objetivo do presente estudo é comparar o estado nutricional, incluindo as dosagens dos níveis séricos de vitaminas A, E e B12 em pacientes alcoolistas com ou sem alterações tróficas das papilas linguais.

MÉTODOs: O estudo caso-controle incluiu 21 pacientes adultos alcoolistas internados em um hospital universitário. Utilizandose de um sistema de fotografia da cavidade oral, dois clínicos independentes classificaram os indivíduos alcoolistas de acordo com a presença ou não de alterações tróficas na língua. Foram registrados os dados antropométricos, a composição corporal pela impedância bioelétrica e os exames laboratoriais para avaliação clínica e nutricional, incluindo dosagens das vitaminas A, E e B12. O estudo incluiu ainda voluntários saudáveis, não alcoolistas como Grupo Controle $(\mathrm{n}=8)$. A comparação entre os grupos foi feita por ANOVA-F ou pelo teste de Kruskal-Wallis, de acordo com a curva de normalidade dos resultados. Foram considerados significativos diferenças com $\mathrm{p}<0,05$.

RESULTADOS: De acordo com a presença de alterações tróficas nas papilas linguais, os pacientes alcoolistas foram alocados no Grupo Língua Despapilada $(n=13)$ e Grupo Língua Normal $(n=8)$, sem diferença estatística quanto à idade $(46,7 \pm 8,7$ vs 46,8 $\pm 15,8$ anos) e gênero masculino (92,3 vs 87,5\%). Os voluntários do Grupo Controle apresentaram 47,5 $\pm 3,1$ anos, sendo $62,5 \%$ do gênero masculino. Os pacientes alcoolistas com hipotrofia papilar apresentaram menor IMC $(18,6 \pm 2,5$ vs $23,8 \pm 3,5$ vs $26,7 \pm 3,6 \mathrm{~kg} / \mathrm{m} 2) \mathrm{e}$ gordura corporal $(7,6 \pm 3,5$ vs $13,3 \pm 6,5$ vs $19,5 \pm 4,9 \mathrm{~kg}$ ), quando comparados com os demais grupos. Em relação ao Grupo Controle, os alcoolistas apresentaram menores valores de hemoglobina (10,8 $\pm 2,2$ vs $11,8 \pm 2,2$ vs $14,5 \pm 1,6 \mathrm{~g} / \mathrm{dL})$ e albumina sérica $(3,6 \pm 0,9$ vs $3,6 \pm 0,8$ vs $4,4 \pm 0,2 \mathrm{~g} / \mathrm{dL})$. Os níveis plasmáticos de vitaminas A, E e B12 foram similares entres os grupos.

Conclusão: Os pacientes alcoolistas com achados físicos de hipotrofia de papilas linguais apresentam menores valores em medidas antropométricas, de hemoglobina e albumina séricas que os grupos Controle ou de alcoolistas sem língua despapilada. Não houve evidências de hipovitaminoses associadas.

Palavras-chave: Alcoolismo; Antropometria; Doenças da língua; Glossite; Vitaminas

Received on 26.01.2010

Approved by the Advisory Board and accepted for publication on 09.03.01.

* Work performed at the Medical School of Ribeirão Preto of the Universidade de São Paulo (FMRP-USP) and Universidade Federal do Triângulo Mineiro (UFMT)

- Uberaba (MG), Brasil.
Conflict of interest: None / Conflito de interesse: Nenhum

Financial funding / Suporte financeiro: National Council of Scientific and Technological Development (Conselho Nacional de Desenvolvimento Científico e Tecnológico - CNPq)

PhD in Internal Medicine - Doctor Professor at the Internal Medicine Department of the Medical School of Ribeirão Preto of the Universidade de São Paulo (FMRP-USP) - São Paulo (SP), Brasil.

Physician - Resident in Cardiology of the Universidade Federal de Uberlândia (UFU) - Uberlândia (MG), Brasil.

Master in Medical Sciences - PhD candidate in Internal Medcine at the Medical School of Ribeirão Preto of the Universidade de São Paulo (FMRP-USP) - São Paulo (SP), Brasil.

PhD in Internal Medicine - Full Professor at the Internal Medicine Department of the Medical School of Ribeirão Preto of the Universidade de São Paulo (FMRP-

USP) - São Paulo (SP), Brasil.

PhD in Internal Medicine - Full Professor at the Internal Medicine Department of the Medical School of the Universidade Federal do Triângulo Mineiro (UFMT) - Uberaba (MG), Brasil.

두릴 by Anais Brasileiros de Dermatologia 


\section{INTRODUCTION}

The systematic inspection of the dorsum of the tongue is an essential part of the physical dermatological examination. ${ }^{1}$ The distinctive texture and appearance of the dorsal tongue are determined by a large number of papillae protruded from the lamina propria to the mucosa epithelium, which gives the tongue its surface roughness and pinkish color. Clinically, there are no criteria on normal tongue except the doctor's subjectivity. Absence of filiform or fungiform papillae in more than $50 \%$ of the tongue gives rise to a "soft " aspect, known as atrophic glossitis or smooth tongue. ${ }^{2,3}$ This finding is seen in $1.3 \%$ to $9.0 \%$ of the non-hospitalized population and in $30 \%$ to $40 \%$ of the hospitalized elderly. $2,4,5$

Papillary atrophy of the tongue may be a manifestation of celiac disease, cardiac failure, syphilis, oral candidiasis, amyloidosis, and conditions such as Sjögrens syndrome, Plummer-Vinson syndrome, and Riley-Day dysautonomia syndrome. ${ }^{1,2,6}$ Atrophic glossitis can also be the result of protein-calorie malnutrition as well as deficiency of iron, vitamin $B_{12}$, folic acid, riboflavin, and niacin. ${ }^{2,3,7,8}$ Although atrophic glossitis is considered a clinical sign of nutritional deficit, its importance is unclear and there are few studies exploring how nutritional disorders affect the oral mucosa, more specifically the tongue.'

In alcoholics, atrophic glossitis may originate from malnutrition or from the direct effect of ethanol on the oral mucosa. ${ }^{2,10}$ Based on the above data we put forward a hypothesis that hospitalized alcoholics with papillary atrophy of the tongue have more nutritional impairment that those without atrophic glossitis. In this context, the aim of the present study was to compare the nutritional status of hospitalized alcoholics with e without papillary atrophy of the tongue and with a healthy control group.

\section{MATERIALS}

The data collection was made in the Universidade Federal do Triângulo Mineiro - MG, Brazil, and this research protocol was approved by an Independent Ethical Committee bureau. All participants signed an informed consent term, including authorization for photographic imaging. Twenty-one adult inpatients with diagnosis of alcoholism were included in this study. All patients ingested Brazilian sugar cane spirits in amounts more than $100 \mathrm{~g}$ ethanol/day of at least 10 years, reported by the patient or their relatives. Exclusion criteria were patients receiving nutritional therapy (enteral or parenteral) and vitamin supplements, those with renal failure, diabetes mellitus and HIV infection. Eight healthy, teetotal volunteers with aged from 40 to 50 years old and without atrophic lesions of the tongue comprised the Control Group.
Photographic documentation of the dorsum of the tongue of all hospitalized alcoholics was obtained. By analyzing the photographs, three independent observers inspected the dorsum and lateral margins of the outer surface of the tongue, in order to identify atrophic alterations in the tongue papillary. The tongue was considered normal when there was regular distribution of the mucosa, papillae easily visualized, with longitudinal and transversal sulcus. Papillary atrophy was diagnosed when there was flattening of the mucosa in the tip and lateral borders of the tongue, giving this organ a smooth, slick aspect (Figure 1). According to these pre-established criteria, hospitalized alcoholics presenting atrophic lesions of the tongue were included in the Atrophic Glossitis Group $(n=13)$, whereas those with preserved tongue papillary were placed in the Normal Tongue Group $(n=8)$.

Anthropometry and bioelectrical impedance analysis to assess body composition were performed after an overnight fasting. Anthropometric assessment was carried out according to standardized procedures and the arm measurement is presented as percentage of the ideal value, taking into account normal values according to gender and age. Bioelectric impedance was measured by means of the RJL Bioelectric Impedance Analyzer (BIA 101-A Detroit, MI, USA).

Blood sample was collected within $72 \mathrm{~h}$ of hospital admission, after an overnight fasting. Biochemical examinations included blood glucose and serum levels of creatinine, aspartate aminotransferase (AST), alanine aminotransferase (ALT), gammaglutamyltransferase (Gamma-GT), sodium, potassium, phosphorus, magnesium, calcium, and albumin, as well as hemoglobin, mean corpuscular volume (MCV) and total lymphocytes. Vitamin A and $\alpha$-tocopherol were determined by high performance liquid chromatography with UV detection (HPLC-UV); Vitamin $\mathrm{B}_{12}$ was measured using the IMMULITE ${ }^{\circledR}$ kit (Siemens).

The statistical analysis was accomplished with the Statistica software package (Version 8.0, Statsoft Inc, Tulsa, Oklahoma). For the comparison of three groups, data were analyzed by ANOVA-F and by the Tukey test for variables with normal distribution and by the Kruskal-Wallis and Dunn tests for variables without normal distribution. The level of significance was set at $\mathrm{p}<0.05$ in all analyses.

\section{RESULTS}

There was complete agreement between three observers in diagnosis of papillary atrophy of the tongue. Among the alcoholics, age, gender and diagnosis upon admission are shown in table 1 . Subjects of control group were aged $47.5 \pm 3.1$ years, and $62.5 \%$ were male. 
TABLE 1: Distribution of age, gender, and secondary diagnosis of hospitalized alcoholic patients with and without atrophic glossitis

\begin{tabular}{lll}
\hline & \multicolumn{1}{c}{ Alcoholic patients } \\
\cline { 2 - 3 } & Atrophic Glossitis Group (n=13) & Normal Tongue Group (n=8) \\
\hline Age (years) & $46.7 \pm 8.7$ & $46.8 \pm 15.8$ \\
Male gender (\%) & 92.3 & 87.5 \\
Cause of hospitalization: & 3 & 3 \\
Acute alcohol intoxication & 4 & - \\
Alcoholic polyneuropathy & 4 & 3 \\
Pellagra & 2 & 2 \\
Major bone trauma & - & - \\
Pneumonia & &
\end{tabular}

Anthropometry and body composition data are summarized in table 2 . Alcoholics with papillary atrophy of the tongue presented lower body weight, body mass index (BMI), arm circumference, tricipital skinfold thickness, muscular arm circumference, and fat body mass.

Table 3 lists the results from the biochemical assessment. Compared with the Control Group, alcoholic patients showed higher gamma-GT and lower hemoglobin and serum albumin. The serum levels of vitamins $\mathrm{A}, \mathrm{E}$, and $\mathrm{B}_{12}$ were similar among groups. Hypovitaminosis $\mathrm{E}$ was detected in three alcoholic patients, two of them in the Atrophic Glossitis Group and one to the Normal Tongue Group.

\section{DISCUSSION}

Although alcoholic patients with papillary atrophy of the tongue showed statistically lower anth- ropometric values compared with the other groups, there was no laboratorial evidence of deficiency of vitamins $\mathrm{A}, \mathrm{E}$, and $\mathrm{B}_{12}$. Lower levels hemoglobin and serum albumin were detected among alcoholic patients irrespective of atrophic glossitis, which suggests that ethanol abuse is involved in chronic nutritional deficiency.

It is well established that chronic ethanol abuse increases lipid oxidation, thermogenesis, and energy expenditure. ${ }^{11}$ Although it is difficult to determine the etiology of nutritional deficiency because of the heterogeneity of organic disorders and the presence of confounding factors associated with secondary malnutrition, alcoholism per se can be considered the cause of body weight reduction. ${ }^{11}$ Although reduction in lean body mass only occurs in patients with alcoholic liver disease, the body fat stores were maintained in chronic alcoholics with or without liver disease. ${ }^{12}$

TABLE 2: Anthropometry and body composition data of alcoholic patients with and without atrophic glossitis, and Control Group

\begin{tabular}{|c|c|c|c|}
\hline & \multicolumn{2}{|c|}{ Alcoholic patients } & \multirow[b]{2}{*}{$\begin{array}{l}\text { Control } \\
\text { Group }(n=8)\end{array}$} \\
\hline & $\begin{array}{l}\text { Atrophic Glossitis } \\
\text { Group }(n=13)\end{array}$ & $\begin{array}{l}\text { Normal Tongue } \\
\text { Group }(n=8)\end{array}$ & \\
\hline Weight $(\mathrm{kg})^{\mathrm{a}}$ & $51.6 \pm 7.1$ & $65.7 \pm 9.6$ & $73.6 \pm 16.2$ \\
\hline Height (m) & $1.67 \pm 0.05$ & $1.66 \pm 0.05$ & $1.65 \pm 0.11$ \\
\hline BMI $\left(\mathrm{kg} / \mathrm{m}^{2}\right)^{\mathrm{a}, \mathrm{b}}$ & $18.6 \pm 2.5$ & $23.8 \pm 3.5$ & $26.7 \pm 3.6$ \\
\hline AC $(\% \text { ideal })^{a}$ & $81.0 \pm 9.2$ & $97.7 \pm 8.7$ & $110.9 \pm 13.5$ \\
\hline TSF (\% ideal $)^{\mathrm{a}, \mathrm{c}}$ & $57.7 \pm 19.5$ & $91.7 \pm 11.3$ & $134.4 \pm 37.5$ \\
\hline MAC (\% ideal) $)^{\mathrm{a}, \mathrm{c}}$ & $73.0 \pm 8.5$ & $84.5 \pm 8.6$ & $105.2 \pm 10.7$ \\
\hline Lean body mass (kg) & $43.5 \pm 6.4$ & $51.8 \pm 3.8$ & $54.0 \pm 12.7$ \\
\hline Fat body mass $(\mathrm{kg})^{a}$ & $7.6 \pm 3.5$ & $13.3 \pm 6.5$ & $19.5 \pm 4.9$ \\
\hline
\end{tabular}

BMI: Body Mass Index / TSF: Tricipital Skinfold / AC: Arm Circumference / MAC: Muscular Arm Circumference

a: $p<0.05$ between Atrophic Glossitis Group and Control Group (ANOVA/Tukey)

b: $p<0.05$ between Atrophic Glossitis Group and Normal Tongue Group (ANOVA/Tukey)

c: $\mathrm{p}<0.05$ between Normal Tongue Group and Control Group (ANOVA/Tukey) 
TABLE 3: Centrality and dispersal values of laboratory data in alcoholic patients with and without atrophic glossitis, and Control Group

\begin{tabular}{|c|c|c|c|}
\hline & \multicolumn{2}{|c|}{ Alcoholic patients } & \multirow[b]{2}{*}{$\begin{array}{l}\text { Control } \\
\text { Group }(n=8)\end{array}$} \\
\hline & $\begin{array}{l}\text { Atrophic Glossitis } \\
\text { Group }(n=13)\end{array}$ & $\begin{array}{l}\text { Normal Tongue } \\
\text { Group }(n=8)\end{array}$ & \\
\hline Blood glucose $(\mathrm{mg} / \mathrm{dL})$ & $85.0(65.0-135.0)$ & $87.5(78.0-192.0)$ & $77.5(65.0-88.0)$ \\
\hline Creatinine $(\mathrm{mg} / \mathrm{dL})$ & $0.8 \pm 0.3$ & $1.1 \pm 0.3$ & $1.0 \pm 0.1$ \\
\hline AST (U/L) & $19.5(10.0-40.0)$ & $63.0(21.0-902.0)$ & $24.5(20.0-44.0)$ \\
\hline $\operatorname{ALT}(\mathrm{U} / \mathrm{L})$ & $17.4(0.7-54.0)$ & $41.0(16.0-158.0)$ & $23.0(12.0-88.0)$ \\
\hline Gamma-GT (U/L) ${ }^{a, c}$ & $82.0(29.0-301.0)$ & $88.0(45.0-1582.0)$ & $31.5(19.0-65.0)$ \\
\hline Sodium (mEq/L) & $135.8 \pm 4.8$ & $134.9 \pm 5.0$ & $138.9 \pm 2.3$ \\
\hline Potassium (mEq/L) & $4.2 \pm 0.4$ & $4.2 \pm 0.6$ & $4.3 \pm 0.4$ \\
\hline Phosphorus (mg/dL) & $4.3 \pm 1.0$ & $4.0 \pm 0.8$ & $3.5 \pm 0.4$ \\
\hline Magnesium (mg/dL) & $1.8 \pm 0.2$ & $1.9 \pm 0.3$ & $1.8 \pm 0.1$ \\
\hline Calcium $(\mathrm{mg} / \mathrm{dL})$ & $9.4 \pm 0.7$ & $9.0 \pm 0.7$ & $9.4 \pm 0.4$ \\
\hline Albumin $(\mathrm{g} / \mathrm{dL})^{\mathrm{a}, \mathrm{c}}$ & $3.6 \pm 0.9$ & $3.6 \pm 0.8$ & $4.4 \pm 0.2$ \\
\hline Hemoglobin $(\mathrm{g} / \mathrm{dL})^{\mathrm{a}, \mathrm{c}}$ & $10.8 \pm 2.2$ & $11.8 \pm 2.2$ & $14.5 \pm 1.6$ \\
\hline MCV (fL) & $92.6 \pm 8.0$ & $94.6 \pm 9.2$ & $89.8 \pm 5.2$ \\
\hline Lymphocytes $\left(10^{3} / \mathrm{mm}^{3}\right)$ & $1.8 \pm 0.4$ & $1.5 \pm 0.4$ & $1.8 \pm 0.5$ \\
\hline Vitamin $\mathrm{A}(\mu \mathrm{mol} / \mathrm{L})$ & $1.9 \pm 0.5$ & $2.2 \pm 1.1$ & $2.4 \pm 0.3$ \\
\hline Vitamin E $(\mu \mathrm{mol} / \mathrm{L})$ & $23.7 \pm 9.3$ & $30.0 \pm 14.0$ & $24.4 \pm 2.9$ \\
\hline Vitamin $B^{12}(p g / m L)$ & $437.5 \pm 233.0$ & $460.1 \pm 268.6$ & $381.3 \pm 151.5$ \\
\hline
\end{tabular}

AST: Aspartate aminotransferase / ALT: Alanine aminotransferase / Gamma-GT: Gamma glutamyltransferase / MCV: Mean Corpuscular Volume / a: $\mathrm{p}<0.05$ between Atrophic Glossitis Group and Control Group (ANOVA/Tukey) / c: p $<0.05$ between Normal Tongue Group and Control Group (ANOVA/Tukey)

Similar to our finding, Fragasso et al described low levels of hemoglobin $(7.5 \pm 2.4 \mathrm{mg} / \mathrm{dl})$ in alcoholic patients. ${ }^{13}$ In our study, anemia, hypoalbuminemia and hyperglycemia were probably manifestations of acute phase response, secondary to the condition that required hospitalization, as observed in numerous clinical situations. ${ }^{14}$

After a short period of protein deprivation, adult rats did not present glossitis or loss of tongue filiform papillae, as demonstrated by scanning electron optical microscopy. ${ }^{9}$ Using anthropometric and biochemical criteria, Bøhmer \& Mower concluded that atrophic glossitis represents a sign of moderate to severe malnutrition, with sensitivity of 0.43 and specificity of 0.67 in the elderly. ${ }^{2}$

Compared to elderly individuals with normal tongue, those with atrophic glossitis do not present differences in terms of plasma levels of various nutritional markers such as vitamin A and vitamin E. ${ }^{5}$ Studying photographs of tongues of 30 elderly subjects, Drinka et al found that cases with overt atrophic glossitis tended to have multiple nutritional deficiencies. ${ }^{7}$ There was high correlation of plasma vitamin $\mathrm{E}$ levels with percentage of normal papillary development, and some authors suggest a role of its antioxidant effect in the maintenance of cellular membrane integrity.
Although symptoms seem to appear later in the course of vitamin deficiency, changes in the oral mucosa were early symptoms of vitamin $B_{12}$ or folate deficiency in a population 70 years or older. ${ }^{15}$ Lower blood folate levels were found in $56 \%$ patients with glossitis, but no reduction was found in serum cobalamin. ${ }^{16}$ In contrast with our study, case reports of atrophic glossitis and glossodynia have often been related to vitamin $B_{12}$ deficiency. ${ }^{17,18}$ Graells et al have recently described four cases of glossitis with linear lesions associated with vitamin $\mathrm{B}_{12}$ deficiency secondary to atrophic gastritis or bacterial overgrowth, in the absence of neurologic symptoms or anemia. ${ }^{19}$

Different from our results, Fragasso et al. documented low levels of cobalamin in $68.2 \%$ of alcoholic patients. Significant positive correlations between vitamin $\mathrm{B}_{12}$ and hepatic enzyme values (gamma-GT) were found in 80 male alcohol-dependent patients. ${ }^{10,13}$ Plasma cobalamin was significantly elevated in the cirrhosis patients, which could be explained by a deficient hepatic clearance of cobalamin bound to haptocorrin. Therefore, for a proper interpretation of vitamin $B_{12}$ levels, it may be clinically relevant to take markers of hepatocellular damage into account. ${ }^{10}$ The methylmalonic acid concentration in serum may be useful for evaluating vitamin $B_{12}$ status in hepatic disease with falsely normal or high concentration of 

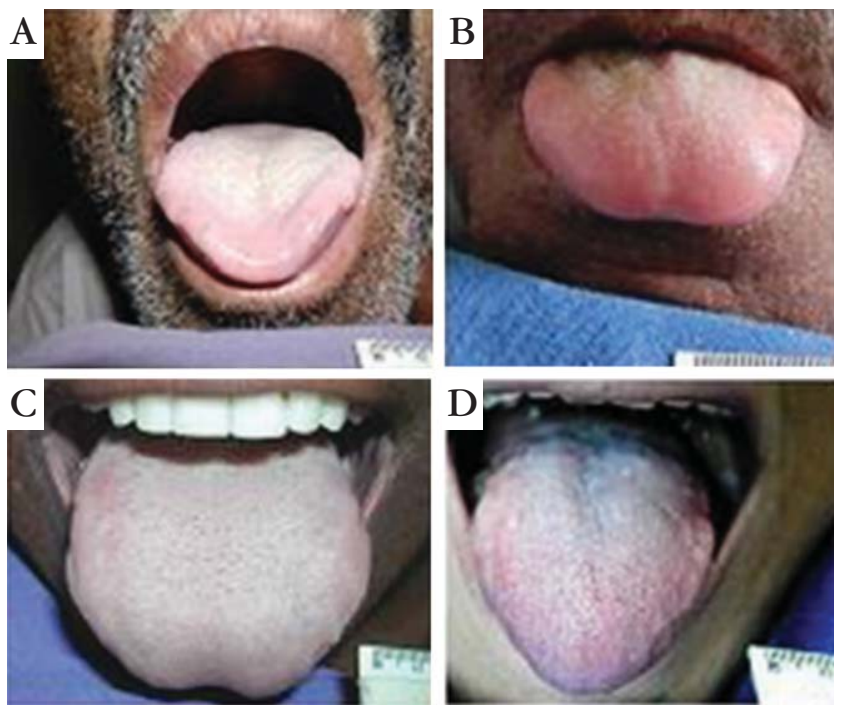

Figure 1: Examples of alcoholic patients with papillary atrophy (A and $\mathrm{B}$ ) and normal lingual papillae (C and D).

cobalamina in serum. ${ }^{21}$

Excessive consumption of alcohol leads to reduction of hepatic vitamin $\mathrm{A}$ in reason of the overlapping metabolic pathways between retinol and ethanol. ${ }^{22}$ Blood retinol of hospitalized German middleclass alcohol consumers with different stages of alcoholic liver disease was lower than healthy control subjects. ${ }^{23}$ Plasma vitamin E level was not different in alcohol consumers and non consumers but alcohol consumers had lower concentrations of serum betacarotene and higher selenium concentrations. ${ }^{24}$

Besides being associated with the loss of taste sensation, it has been shown that ethanol and its metabolite acetaldehyde increase epithelium permeability, thereby causing oral mucosal atrophy correlated with hyper regeneration, augmented epithelial cell proliferation in the dorsal surface of the tongue mucosa, and decreased lipid peroxidation levels. ${ }^{25-28}$ It is possible that changes due to ethanol abuse per se mask changes in the tongue dorsum resulting from vitamin deficiency. Further studies focusing on the chronic effects of alcohol on the ventral tongue should be conducted in animals with or without nutritional deficiencies.

It is worthwhile to stress four limitations of our work. First, one should mention the small sample size and the diversity of clinical diagnosis among the alcoholic patients. Second, other water soluble vitamins and minerals that can also be related to atrophic glossitis were not measured. ${ }^{3}$ Alcoholics individuals may have hepatic dysfunction that alters serum lipoproteins. Due to the fact the serum values of some vitamins may be influenced by levels of lipoproteins, it is recommended that vitamin $\mathrm{E}$ is corrected by the levels of circulating fat. ${ }^{29}$ And lastly, data on nutritional history is not presented, even though the questionnaire about the frequency of semi-quantitative food intake was applied whenever possible. We chose to exclude such data because of the overestimation of energy intake due to probable intentional or non-intentional tendency of the interviewee to give replies based on what is more socially accepted..$^{30}$

\section{CONCLUSION}

In conclusion, our results indicate that alterations in the tongue papillary of hospitalized alcoholics occur in parallel with reduced anthropometric measures, anemia e hypoalbuminemia. There is no evidence of the influence of hypovitaminosis $\mathrm{A}, \mathrm{E}$ and $\mathrm{B}_{12}$ in atrophic glossitis of chronic alcoholics. $\square$ 


\section{REFERENCES}

1. 1.Gonçalves LM, Bezerra Júnior JRS, Cruz MCFN. Clinical evaluation of oral lesions associated with dermatologic diseases. An Bras Dermatol. 2010;85:150-6.

2. Bøhmer T, Mowé M. The association between atrophic glossitis and protein-calorie malnutrition in old age. Age Ageing. 2000;29:47-50.

3. Byrd JA, Bruce AJ, Rogers RS 3rd. Glossitis and other tongue disorders. Dermatol Clin. 2003;21:123-34.

4. Dombi C, Czeglédy A. Incidence of tongue diseases based on epidemiologic studies (review of the literature). Fogorv Sz. 1992;85:335-41.

5. Sweeney MP, Bagg J, Fell GS, Yip B. The relationship between micronutrient depletion and oral health in geriatrics. J Oral Pathol Med. 1994;23:168-71.

6. Pastore L, Carroccio A, Compilato D, Panzarella V, Serpico R, Lo Muzio L. Oral manifestations of celiac disease. J Clin Gastroenterol. 2008;42:224-32.

7. Drinka PJ, Langer EH, Voeks SK, Scott L, Morrow FD. Nutritional correlates of atrophic glossitis: possible role of vitamin $E$ in papillary atrophy. J Am Coll Nutr. 1993;12:14-20.

8. Enwald CV, Drinka PJ, Swortz C, Langer EH, Voeks SK. Iron status in atrophic glossitis: a pilot study. Wis Med J. 1993;92:570-3.

9. Abreu MAMM, Weckx LLM, Hitomi C, Hirata W. Aspectos histológicos e ultraestruturais da língua em ratos desnutridos. Rev Bras Otorrinolaringol. 2006;72:523-7.

10. Himmerich H, Anghelescu I, Klawe C, Szegedi A. Vitamin B12 and hepatic enzyme serum levels correlate in male alcohol-dependent patients. Alcohol Alcohol. 2001;36:26-8.

11. Addolorato G, Capristo E, Greco AV, Stefanini GF, Gasbarrini G. Influence of chronic alcohol abuse on body weight and energy metabolism: is excess ethanol consumption a risk factor for obesity or malnutrition? J Intern Med. 1998;244:387-95.

12. Sarin SK, Dhingra N, Bansal A, Malhotra S, Guptan RC. Dietary and nutritional abnormalities in alcoholic liver disease: a comparison with chronic alcoholics without liver disease. Am J Gastroenterol. 1997;92:777-83.

13. Fragasso A, Mannarella C, Ciancio A, Sacco A. Functional vitamin B12 deficiency in alcoholics: An intriguing finding in a retrospective study of megaloblastic anemic patients. Eur J Int Med. 2010;21:97-100.

14. Cunha DF, Barbosa AA, Manfrin A, Tiveron FS, Cunha SFC. Sodium serum levels in hypoalbuminemic adults at general medical wards. Rev Hosp Clin Fac Med Sao Paulo. 1999;54:39-42.

15. Björkegren K, Svärdsudd K. Reported symptoms and clinical findings in relation to serum cobalamin, folate, methylmalonic acid and total homocysteine among elderly Swedes: a population-based study. J Intern Med. 2003;254:343-52.

16. Thongprasom K, Youngnak P, Aneksuk V. Folate and vitamin B12 levels in patients with oral lichen planus, stomatitis or glossitis. Southeast Asian J Trop Med Public Health. 2001;32:643-7.

17. Pétavy-Catala $\mathrm{C}$, Fontès $\mathrm{V}$, Gironet $\mathrm{N}$, Hüttenberger $\mathrm{B}$, Lorette $\mathrm{G}$, Vaillant L. Clinical manifestations of the mouth revealing Vitamin B12 deficiency before the onset of anemia. Ann Dermatol Venereol. 2003;130:191-4.

18. Lehman JS, Bruce AJ, Rogers RS. Atrophic glossitis from vitamin B12 deficiency: a case misdiagnosed as burning mouth disorder. J Periodontol. 2006;77:2090-2.
19. Graells J, Ojeda RM, Muniesa C, Gonzalez J, Saavedra J. Glossitis with linear lesions: an early sign of vitamin B12 deficiency. J Am Acad Dermatol. 2009;60:498-500.

20. Lambert D, Benhayoun S, Adjalla C, Gélot MM, Renkes P, Gérard P, et al. Alcoholic cirrhosis and cobalamin metabolism. Digestion. 1997;58:64-71.

21. Hagelskjaer $L$, Rasmussen $K$. Methylmalonic acid concentration in serum not affected in hepatic disease. Clin Chem. 1992;38:493-5.

22. Leo MA, Lieber CS. Alcohol, vitamin A, and beta-carotene: Adverse interations, including hepatotoxicity and carcinogenicity. Am J Clin Nutr. 1999;69:1071-85.

23. Bergheim I, Parlesak A, Dierks C, Bode JC, Bode C. Nutritional deficiencies in German middle-class male alcohol consumers: relation to dietary intake and severity of liver disease. Eur J Clin Nutr. 2003;57:431-8.

24. Galan P, Viteri FE, Bertrais S, Czernichow S, Faure H, Arnaud J, et al. Serum concentrations of beta-carotene, vitamins $C$ and $E$, zinc and selenium are influenced by sex, age, diet, smoking status, alcohol consumption and corpulence in a general French adult population. Eur J Clin Nutr. 2005;59:1181-90.

25. Galan P, Viteri FE, Bertrais S, Czernichow S, Faure H, Arnaud J,et al. Clinical and biological features associated with taste loss in internal medicine patients. A cross-sectional study of 100 cases. Appetite. 2005;44:163-9.

26. Howie NM, Trigkas TK, Cruchley AT, Wertz PW, Squier CA, Williams DM. Short-term exposure to alcohol increases the permeability of human oral mucosa. Oral Dis. 2001;7:349-54.

27. Maier H, Weidauer H, Zöller J, Seitz HK, Flentje M, Mall G, et al. Effect of chronic alcohol consumption on the morphology of the oral mucosa. Alcohol Clin Exp Res. 1994;18:387-91.

28. Carrard VC, Pires AS, Mendez M, Mattos F, Moreira JCF, Sant'Ana Filho M. Effects of acute alcohol consumption and vitamin $\mathrm{E}$ co-treatment on oxidative stress parameters in rats tongue. Food Chem Toxicol. 2009;47:1058-63.

29. Luo M, Estívariz CF, Schleicher RL, Bazargan N, Leader LM, Galloway JR et al. Prospective analysis of serum carotenoids, vitamin $\mathrm{A}$, and tocopherols in adults with short bowel syndrome undergoing intestinal rehabilitation. Nutrition. 2009;25:400-7.

30. Maurer J, Taren DL, Teixeira PJ, Thomson CA, Lohman TG, Going SB, et al. The psychosocial and behavioral characteristics related to energy misreporting. Nutr Rev. 2006;64:53-66.

MAILING ADDRESS / ENDEREÇO PARA CORRESPONDÊNCIA:
Selma Freire de Carvalho da CUnha
Departamento de Clínica Médica
Faculdade de Medicina de Ribeirão Preto.
Av. Bandeirantes, 3900.
Cep 14048-900 Ribeirão Preto-SP, Brazil
Phone: 55-16 3633-0036 / 55-16 3602-3369
Fax: 55-163633-6695
E-mail: sfreire@fmrp.usp.br

How to cite this article/Como citar este artigo: Cunha SFC, Melo DA, Braga CBM, Vannucchi H, Cunha DF. Papillary atrophy of the tongue and nutritional status of hospitalized alcoholics. An Bras Dermatol. 2012;87(1):84-9. 